without operation. Of the 21 women 15 had collagen disorder, which, though varying in tempo in the individual patient, had a tendency towards marked chronicity in the hands. It was also characteristically resistant to sympathectomy, with the proviso that the operation allowed the fingers to remain healed in more than half the patients with actual tissue necrosis.

Until more is known of the prognosis of digital necrosis in the untreated patient it seems reasonable to continue to recommend sympathectomy to all patients of both sexes with trophic changes, bearing in mind that amelioration rather than cure is the best that can be expected in most women. This advice applies whatever the nature of the underlying condition, since, as already mentioned, some permanent improvement can be expected even in severe collagen disorder. In view of the poor prognosis in women without actual necrosis, 11 out of $12(92 \%)$ being uninfluenced or eventually worse, it seems doubtful if the operation should be advised in these circumstances.

\section{Summary}

Forty-three patients are reviewed in whom upper thoracic sympathectomy was performed for severe digital ischaemia due to digital artery obstruction, confirmed by arteriography in 34 . The extent of digital artery blockage failed to correlate with the severity of the symptoms. The probable underlying pathological conditions at final review was atherosclerosis in 23, acrosclerosis in 12, systemic scleroderma in six, and neuropathy and rheumatoid arthritis in one each.

Actual necrosis of one or more fingers was the presenting symptom in 23 patients and severe episodic ischaemia without necrosis in 20 , but this variation in symptomatology related to rapidity of onset of the thrombosis rather than to the underlying pathology.

The late results of sympathectomy were best in men, about $60 \%$ of whom were completely cured of their symptoms. Of the women $56 \%$ were cured of necrosis, but milder ischaemic symptoms usually persisted; when sympathectomy was performed in the absence of necrosis, only $8 \%$ of women received permanent benefit.

When digital necrosis is present upper thoracic sympathectomy can be expected to confer permanent benefit in rather more than half the patients, even in the presence of collagen disorder. Sympathectomy should not be advised in women when digital ischaemia is unaccompanied by local necrosis.

I would like to thank Professor G. W. Taylor for permission to study a number of patients under his care.

\section{REFBRENCES}

Birnstingl, M. (1967). In Vascular Surgery and Reticuloendothelial System, edited by G. W. Taylor and J. F. Wilkinson, Chap. 6. London. In press.

Catchpole, B. N., Jepson, R. P., and Kellgren, J. H. (1954). Ann. rheum. Dis., 13, 302 .

de Takats, G., and Fowler, E. F. (1962). 7. Amer. med. Ass., 179, 1 Jepson, R. P. (1956). Circulation, 14, 1084

Johnston, E. N. M., Summerly, R., and Birnstingl, M. (1965). Brit. med. F., 1, 962 .

Lewis, T., and Pickering, G. W. (1934). Clin. Sci., 1, 327.

Marchand, F. (1904). Verh. disch. Kongr. inn. Med., 21, 23

Mitchell, J. R. A., and Schwartz, C. J. (1965). Arterial Disease. Oxford. Phillips, J., and Burch, G. E. (1958). Amer. F. med. Sci., 235, 668.

\title{
Total Dose Imferon (Iron-dextran Complex) Infusion Therapy in Severe Hookworm Anaemia
}

\author{
KANTI M. PATEL,* M.B., B.S., M.R.C.P.ED., M.R.C.P.GLASG., D.C.H., D.T.M.\&H. \\ J. A. TULLOCH, $†$ M.C., M.D., M.R.C.P., F.R.C.P.ED.
}

Brit. med. F., 1967, 2, 605-607

Anaemia is one of the commonest medical problems in Uganda, East Africa. Most cases are of iron-deficiency type, and hookworm infection is an important cause (Meredith and Eyekuze, 1962). A large section of the population of East Africa are infected with hookworm, usually Necator americanus (Wilks and Patel, 1967). Anaemia caused by hookworm infection is often very severe. Along with the eradication of the infestation, oral iron is important for satisfactory treatment. Unless treatment is continued conscientiously for several months after the haemoglobin level is restored to normal there is no chance of replenishing the iron reserves, which are necessary to protect against relapse when reinfection with hookworm occurs (Pritchard and Mason, 1964). Reinfection is exceedingly common in Uganda. Continuance of outpatient supervision is difficult to arrange. Many of these patients stop taking oral iron when they leave hospital, and do not return to the outpatient clinic until severe anaemia has recurred. This problem of uncertainty prompted us to investigate the effectiveness of a

\footnotetext{
* Senior Lecturer in Medicine, Makerere University College Medical School, Kampala, Uganda, E. Africa.

t Formerly Professor of Medicine, Makerere University College Medical School, Kampala, Uganda, East Africa. Now Consultant Physician Stracathro Hospital, Brechin, Scotland.
}

single intravenous infusion of iron. The preparation used was iron-dextran complex (Imferon). This was chosen because of its extremely low toxicity, high stability, freedom from ionic iron, and established response in haemoglobin increase (Varde, 1964).

\section{Patients and Methods}

Sixty patients were included in the study. Their haemoglobin was $4 \mathrm{~g} . / 100 \mathrm{ml}$. or less, their faeces contained more than 200 worms-that is, 30,000 hookworm ova per gramme of faecesand there was no other obvious cause for the anaemia. Irondeficiency anaemia was established in each case by peripheral blood film and bone marrow. All patients were in hospital. Eight additional patients were originally included in the comparative study but were withdrawn because of complicating conditions-for example, cirrhosis of the liver and pulmonary tuberculosis. Forty-five patients were treated with intravenous infusion of Imferon. The amount given was determined on a body-weight and haemoglobin-deficit basis from the table supplied by the manufacturers; the single doses ranged fro.n 1,250 to $3,750 \mathrm{mg}$. Dilution was with normal saline, and the solution was never stronger than $5 \% \mathrm{v} / \mathrm{v}$. The first $50 \mathrm{nd}$. 
was infused at 20 drops per minute. If no abnormal reactions were observed the remainder was infused at 40-60 drops per minute.

Fifteen patients were treated with two tablets of ferrous sulphate three times daily (360 mg. iron per day). Thirty-five patients who were treated similarly were studied retrospectively.

The patients in both groups were twice dewormed with tetrachloroethylene $(4 \mathrm{ml}$.). Response to treatment was determined by serial measurements of haemoglobin, packed cell volume, and reticulocyte count twice weekly.

\section{Results}

The results of the study are summarized in the Table and Fig. 1. The initial mean haemoglobin value was similar for both groups-3.1 g. $/ 100 \mathrm{ml}$. for the Imferon group and $3.3 \mathrm{~g}$./ $100 \mathrm{ml}$. for the ferrous sulphate group. The mean hookworm load was heavy for both groups (see Table). All patients responded promptly with a reticulocytosis and an increase in haemoglobin. The response was most pronounced in the first two weeks after starting treatment with deworming plus Imferon infusion or oral ferrous sulphate. The rise in haemoglobin was, however, more brisk in the group treated with Imferon$2.2 \mathrm{~g} . / 100 \mathrm{ml}$./week during the first two weeks compared with $1.3 \mathrm{~g} . / 100 \mathrm{ml}$./week in the ferrous sulphate group. The overall rise of haemoglobin per week in the Imferon group was $1.6 \mathrm{~g} . /$ $100 \mathrm{ml}$., compared with $1.0 \mathrm{~g} . / 100 \mathrm{ml}$. in the ferrous sulphate group. The difference in response was statistically significant $(\mathrm{P}<0.001)$. The mean inpatient follow-up was 5.5 weeks in

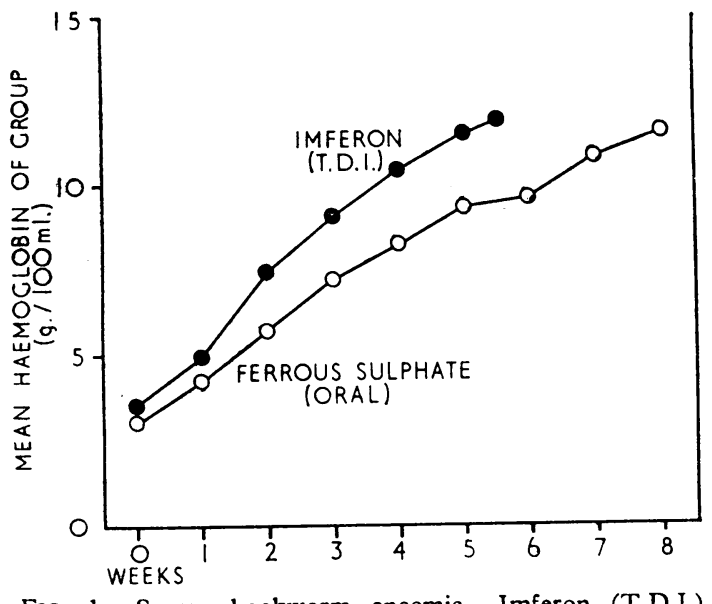

FIG. 1.-Severe hookworm anaemia. Imferon (T.D.I.) compared with ferrous sulphate.

the Imferon and 8 weeks in the ferrous sulphate group. Mean haemoglobin on discharge was $12 \mathrm{~g} . / 100 \mathrm{ml}$. in the Imferon group. At this time the mean haemoglobin in the ferrous sulphate group was $9.5 \mathrm{~g} . / 100 \mathrm{ml}$., and on discharge it was 11.8 g. $/ 100 \mathrm{ml}$.

A retrospective study of 35 patients with severe hookworm anaemia treated with oral ferrous sulphate over the previous four years showed that the average haemoglobin rise was similar to that in the 15 patients similarly treated in the present study.

The 60 patients were followed up in the outpatient clinic. Attendance was not entirely satisfactory, because of the long distances from the patients' homes to Mulago Hospital, and often the high cost of transport. The patients who had had Imferon were given yeast tablets as a placebo ; the other patients were continued on oral ferrous sulphate (three tablets a day-that is, $180 \mathrm{mg}$. iron a day). Many patients in both groups took their tablets irregularly. Reinfection with hookworm was almost universal. It usually occurred two to four months after the patient's discharge from hospital. Sixteen patients who had had Imferon and had been followed for 9 to 16 months became reinfected with hookworm, but their haemoglobin levels remained normal. Six patients who had had oral iron and had been followed for 9 to 17 months also became reinfected with hookworm and were anaemic. Fig. 2 shows the response to oral ferrous sulphate of a man aged 40 with severe hookworm anaemia. He was dewormed twice with tetrachloroethylene (4 ml.) at the beginning of iron therapy. The response to oral iron which he had had for seven months was satisfactory. However, seven months after the therapy he was readmitted with severe iron-deficiency anaemia, and was heavily reinfected with hookworm. Fig. 3 shows the response of a man aged 47

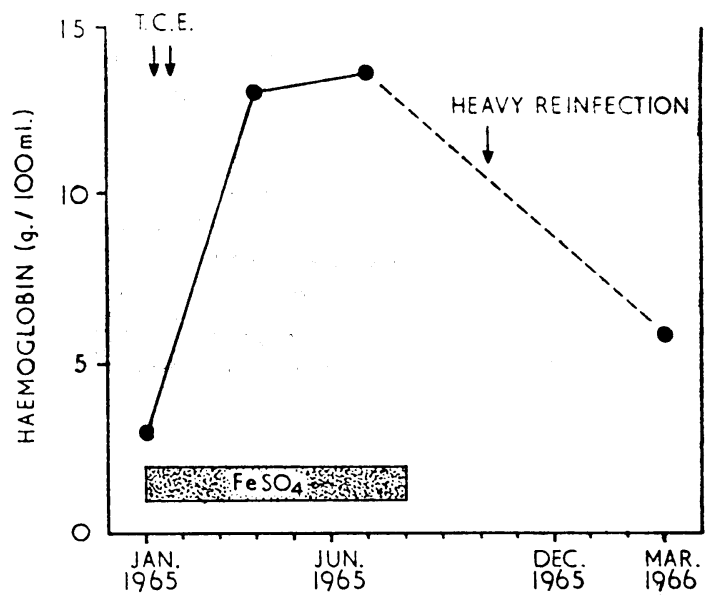

Fig 2-Response to oral ferrous sulphate of a man aged 40 with hookworm anaemia.

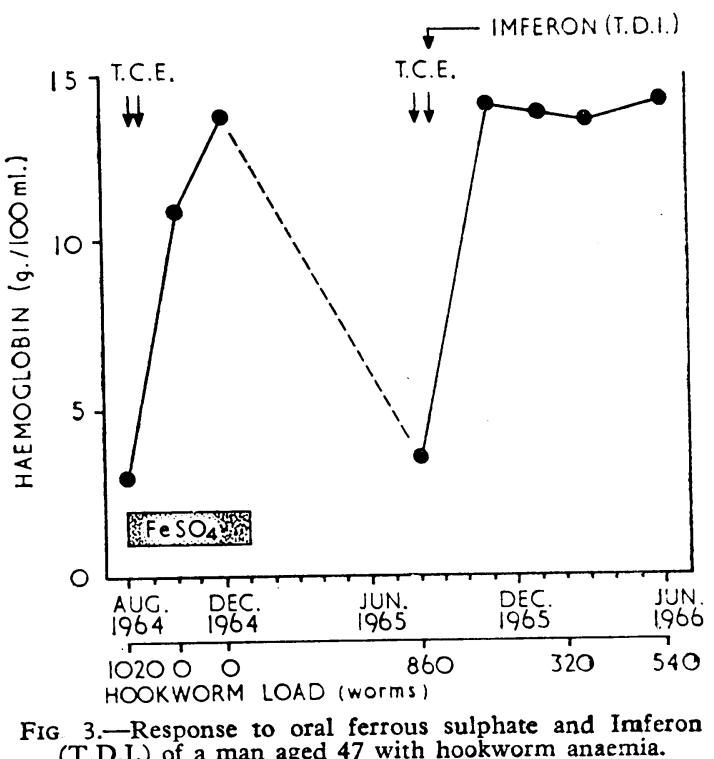

Total Dose Imferon Compared with Ferrous Sulphate

\begin{tabular}{|c|c|c|c|c|c|c|c|c|c|c|}
\hline & \multirow[t]{2}{*}{ No. } & \multicolumn{2}{|c|}{ Sex } & \multirow{2}{*}{$\begin{array}{c}\text { Age } \\
\text { (Years) }\end{array}$} & \multirow{2}{*}{$\begin{array}{l}\text { Hookworm Load } \\
\text { (Worms) }\end{array}$} & Initial $\mathrm{Hb}$ & $\begin{array}{c}\text { Hb on } \\
\text { Discharge }\end{array}$ & $\begin{array}{l}\text { Hb Rise per } \\
\text { Week (for 1st } \\
2 \text { Weeks) }\end{array}$ & \multirow[t]{2}{*}{$\begin{array}{l}\text { Follow-up } \\
\text { (Weeks) }\end{array}$} & \multirow{2}{*}{$\begin{array}{c}\text { Hb (g./100 ml.) } \\
\text { Rise per Week } \\
\text { (Overall) }\end{array}$} \\
\hline & & $M$ & $\mathrm{~F}$ & & & \multicolumn{3}{|c|}{ g. $/ 100 \mathrm{ml}}$. & & \\
\hline $\begin{array}{l}\text { Imferon } \\
\text { Ferrous sulphate }\end{array}$ & $\begin{array}{l}45 \\
15\end{array}$ & $\begin{array}{r}24 \\
9\end{array}$ & ${ }_{6}^{21}$ & $\begin{array}{l}41(13-70) \\
41(17-65)\end{array}$ & $\begin{array}{l}650(300-2,100) \\
520(300-2,300)\end{array}$ & $\begin{array}{l}3 \cdot 1(1 \cdot 8-4) \\
3 \cdot 3(1 \cdot 8-4 \cdot 2)\end{array}$ & $\begin{array}{l}12(9-13 \cdot 8) \\
11 \cdot 8(9-13 \cdot 4)\end{array}$ & $\begin{array}{l}2 \cdot 2(1 \cdot 6-3) \\
1 \cdot 3^{*}\end{array}$ & $\begin{array}{l}5.5(3-9) \\
8(5-11.5)\end{array}$ & $\begin{array}{l}1 \cdot 6(1 \cdot 2-1 \cdot 9) \\
1 \cdot 0 *(2-7-1 \cdot 4)\end{array}$ \\
\hline
\end{tabular}


with severe hookworm anaemia (Hb 3 g. $/ 100 \mathrm{ml}$., hookworm load of 1,020 worms) to oral ferrous sulphate and Imferon (T.D.I.). He responded well to deworming with tetrachlorodiphenyl-ethane (T.C.E.) and ferrous sulphate, which he had for five months. However, seven months later he was admitted with recurrence of severe hookworm anaemia (Hb $3.6 \mathrm{~g} . / 100 \mathrm{ml}$. and hookworm load of 860 worms). This time he was treated with T.C.E. and total dose Imferon, to which he made a good response. The haemoglobin reached normal level within three months. He was followed for 10 months after the therapy. During this period he became reinfected with hookworm, but his haemoglobin remained consistently high.

There were no general reactions at the time of Imferon infusion. Five patients, however, had thrombophlebitis at the site of infusion, and two developed fever two days and three days respectively after the infusion.

\section{Discussion}

The total dose Imferon infusion technique provides a safe, convenient, and rapidly effective means of replenishing the patient's body iron (Marchasin and Wallerstein, 1964). It must be stressed, however, that severe systemic reactions may occur, and this treatment should always be carried out with due caution. Oral iron therapy would take many months to be effective, and it is very difficult to supervise in outpatients. The haematological response was better with Imferon. However, with both forms of iron therapy the lower the initial haemoglobin level the more rapid and dramatic the response. It was most marked during the first two weeks after infusion therapy. When the single infusion is completed there is absolute certainty that the patient has received the precise amount of iron required for the complete restoration of haemo- globin, body iron reserves, and tissue iron. The follow-up study has shown that because of this the patients treated with Imferon did not become anaemic even though they became reinfected with hookworm. The patients preferred to have their treatment in one day, and therefore showed a preference for total dose Imferon infusion therapy.

\section{Summary}

The response of 45 patients with severe hookworm anaemia to total dose Imferon infusion was compared with that of 15 patients given oral ferrous sulphate. Recovery after Imferon was more rapid. Abnormal reactions to Imferon were infrequent and mild. Follow-up studies showed that reinfection with hookworm was extremely common. Patients treated 'with ferrous sulphate quickly relapsed into severe anaemia when infection with hookworm recurred. This was in marked contrast with the Imferon-treated group, whose haemoglobin levels still remained uniformly high. This must be attributed to the replacement of the iron reserves by total dose Imferon, and is one of the main advantages of using this technique in anaemias occurring in the tropics.

We are grateful to our colleagues for allowing us access to their patients, and to Dr. G. D. Ballantyne, of Fison Pharmaceuticals Ltd., England, for providing Imferon.

\section{REFERENCES}

Marchasin, S., and Wallerstein, R. O. (1964). Blood, 23, 354.

Meredith, J. S., and Eyekuze, V. M. (1962). E. Afr. med. F., 39, 250. Pritchard, J. A., and Mason, R. A. (1964). F. Amer. med. Ass., 190, 897. Varde, K. N. (1964). F. Obstet. Gynaec. Brit. Cwith, 71, 919. Wilks, N. E., and Patel, K. M. (1967). To be published.

\title{
Choledochoduodenostomy in Treatment of Chronic Pancreatitis and Choledocholithiasis
}

\author{
J. N. BURGESS,* M.B., B.S., F.R.C.S. ; H. A. KIDD, † F.R.C.S., F.R.C.S.ED.
}

Brit. med. F., 1967, 2, 607-609

Choledochoduodenostomy is not often performed in this country. We feel that it has a valuable part to play in the treatment of chronic relapsing pancreatitis, and that it is the procedure of choice in choledocholithiasis. Our purpose here is to show that this neglected operation is neither difficult nor dangerous, and should be much more widely used. It has suffered from the somewhat theoretical objections that such an anastomosis is difficult to perform, that it would predispose to ascending cholangitis, and that stricture of the common bile duct above the anastomosis would occur in a high proportion of patients owing to reflux of duodenal contents. We hope that this paper will help to dispel these doubts and give the procedure its rightful place among surgical techniques.

\section{Indications}

We feel that the indications for performing this operation are as follows:

1. Chronic pancreatitis, either diagnosed preoperatively and confirmed at operation or encountered at operation. The condition may be either pancreatitis alone or pancreatitis associated with calculous disease of the biliary tract.

* Researci Assistant, Mayo Clinic, Rochester, Minnesota. t Consultant Surgeon, St. Helier Hospital, Carshalton, Surrey.
2. Choledocholithiasis: the stones in the common bile duct may be associated with stones in the gall bladder, in which case cholecystectomy should also be performed. The patient may previously have undergone cholecystectomy with or without exploration of the common bile duct for calculous disease.

We have also used this procedure for palliation in cases of irremovable carcinoma of the head of the pancreas, but these cases do not constitute any part of the series here presented.

\section{Present Series}

This series comprised 31 patients treated in a busy general surgical unit by choledochoduodenostomy in the 10-year period from 1 June 1956 to 1 June 1966. No patient was refused operation because of advanced age or general debility, and the operations were performed by one of us (H. A. K.) or his senior registrar.

Twenty-seven patients were followed up by personal interview by one of us (J.N.B.) ; three were over 85 years of age and were seen by their own general practitioners as it was not thought justifiable to bring these very old people to hospital, and one was in a mental hospital and was interviewed by his psychiatrist. All were asked if they were satisfied with the result of the operation and if they ever suffered abdominal pain or indigestion since it was completed. They were specifically 